\title{
CONSIDERATุII PRIVIND FORMAREA DEPRINDERILOR MOTRICE SPECIFICE ACTIVITĂȚILOR FIZICE CU CARACTER MILITAR
}

\author{
CONSIDERATIONS REGARDING BUILDING MOTOR SKILLS \\ SPECIFIC TO MILITARY PHYSICAL ACTIVITIES
}

Col.instr.av.dr. Alin PELMUȘ*

\begin{abstract}
Articolul, în prima parte, abordează aspecte care țin de conceptul, caracteristicile și tipologia deprinderilor motrice. Ulterior, sunt relevate unele aprecieri legate de mecanismul de formare a deprinderilor motrice și sunt evidențiate etapele formării acestora, insistându-se pe cele de natură metodică. De asemenea, pe tot parcursul articolului, se aduc în atenție opinii privind complexitatea procesului de formare a deprinderilor motrice cu aplicabilitate în sistemul militar și importanța deosebită a acestora în cadrul instruirii pentru luptă.
\end{abstract}

In its first part, the article addresses issues related to the concept, characteristics and typology of motor skills. Subsequently, some evaluations related to the mechanism of building motor skills are revealed and their stages highlighted, insisting on the methodical ones. Throughout the article, opinions are also expressed about the complexity of the motor skills training process applicable in the military system and their special importance in combat training.

Cuvinte-cheie: deprinderi motrice; instruire militară; formare; consolidare; perfecționare; complexe.

Keywords: motor skills; military training; formation; consolidation; improvement; complexity.

Sfera deprinderilor nu se limitează numai la activitatea motrică. Majoritatea deprinderilor pe care le întreprindem zilnic au, în componența lor, elemente realizate pe fondul unor operații, formate, în prealabil, în școală sau familie. În activitățile umane cotidiene, întâlnim deprinderi intelectuale, senzoriale, de muncă, artistice, sportive etc.

Așadar, deprinderile sunt modalități de acțiune, tehnici de execuție în cadrul unor activități diverse, care, consolidate și perfecționate prin repetări multiple, devin componente automatizate ale acestor activități. Instruirea militară este procesul în cadrul căruia sunt necesare foarte multe deprinderi, cele motrice ocupând un loc aparte.

Referitor la deprinderile motrice, problema acestora este larg tratată în literatura de specialitate, fiindu-i consacrate numeroase studii. Pentru elucidarea problemei deprinderilor motrice, se întâmpină încă greutăți, din cauza tratării acestora din mai multe puncte de vedere, nuanțate și interpretate, în funcție de specialitatea autorilor,

\footnotetext{
*Universitatea Națională de Apărare „Carol I” e-mail:pelmusalin@yahoo.com
}

astfel: fiziologic, psihologic, pedagogic, sportiv sau din perspectiva teoriei educației fizice.

Deprinderile motrice sunt acțiuni motrice umane, care apar și se formează de-a lungul întregii vieţi individuale prin exersare conștientă și sistematică. Ele se formează fie ca urmare a evoluţiei omului, fie ca urmare a participării în procese de instruire organizate, aşa cum este şi educația fizică militară. Spre deosebire de procesele de instruire special organizate (educația fizică, antrenamentul sportiv, instruirea militară etc.), în practica vieții, se pot însuşi frecvent și deprinderi motrice greșite ca mecanism de execuție, care, ulterior, sunt greu de remediat.

Formarea deprinderilor motrice reprezintă o activitate reflex condiționată, bazată pe repetarea interacțiunii dintre diferitele excitații (chinestezice, vizuale, auditive etc.), transmise scoarței cerebrale în aceeași ordine și cu aceeași intensitate. Reflexele astfel dobândite unește componentele acțiunii, stabilind un lanț de conectări multiple și complexe între analizatori, zonele senzitive și motorii din scoarță, sistematic organizate prin intermediul celui de-al doilea sistem de semnalizare. 
Din multitudinea de definiții ale deprinderilor motrice întâlnite în literatura de specialitate, abordarea lui Whiting pare cea mai concludentă și completă: ,... o serie de acţiuni motrice complexe, intenționate, implicând un lanț de mecanisme senzoriale, centrale și motorii care prin procesul învăţării au devenit organizate și coordonate, astfel încât permit realizarea unor obiective, cu maximum de siguranţă"’.

Din acest punct de vedere, dar și din considerațiile majorității autorilor, se constată că deprinderile motrice sunt văzute drept comportamente, orientate către atingerea anumitor scopuri prin cheltuieli minime de energie, și pot fi dobândite numai în urma exersării, cea care atrage după sine creșterea gradului de perfecțiune a mișcărilor efectuate, realizarea acestora cu ușurință și precizie.

În faza superioară a însușirii deprinderilor motrice, atunci când putem vorbi de perfecțiune (sau „măiestrie motrică”, termen întâlnit în domeniul educației fizice și sportului), se formează anumite senzații complexe, care sunt intitulate expresiv „simțuri” (se poate vorbi de simțul mingii, de simţul rachetei sau al paletei, de simţul apei sau al zăpezii, de simțul ștachetei etc.) $)^{2}$.

Deci, deprinderea motrică este un proces care include atât exersarea, cât și alte mijloace de natură psihopedagogică complexă. Psihologul Mihai Epuran evidențiază următoarele caracteristici principale ale deprinderilor motrice: sunt parte a conduitei voluntare a omului, dobândind ușurință și exactitate pe baza efortului de voință; sunt incluse în diverse „familii de mișcări”, aparținând unor comportamente motrice clar definite; sunt integrate în „sisteme de mișcări” ca unități mai simple; se manifestă precum sistemele ce dispun de feedback corectiv, de fiecare dată când, în executarea acestora, intervin imprecizii; implică o capacitate sporită de diferențiere fină a mișcărilor, pe baza unor informații senzorial-perceptive; chiar dacă se execută în condiții variabile, dețin o stabilitate relativă, fapt ce determină impunerea lor în conduita motrică (important este ca deprinderile să fie însușite corect de la început, întrucât corijarea ulterioară este foarte dificilă); îmbracă toate particularitățile subiecților care le execută, astfel încât, la nivelurile superioare de învățare și aplicare, se poate discuta de „stil”; procesul de formare a acestora este condiționat de anumiți factori obiectivi și subiectivi (aptitudinile, motivația, atitudinea, ambianța și condițiile educaționale, capacitatea de autoapreciere etc.) $)^{3}$.

În literatura de specialitate întâlnim foarte multe criterii după care sunt stabilite tipurile sau categoriile de deprinderi motrice. Din multitudinea de criterii, pentru acest articol am ales următoarele:

a) În funcție de nivelul automatizării:

- deprinderi motrice elementare. Acestea sunt automatizate complet, fiind alcătuite dintr-un lanţ de mişcări cu caracter fazic, care se repetă în aceeaşi succesiune (mișcări ciclice precum mersul, alergarea, înotul, ciclismul etc.);

- deprinderi motrice complexe. Acestea sunt automatizate parţial, fiind alcătuite din deprinderi elementare şi din unele mişcări neautomatizate ori incomplet automatizate (deprinderi din jocurile sportive şi din ramuri de sport sau probe aciclice precum gimnastica, sporturile combat, săriturile, aruncările etc.).

b) În funcție de finalitatea folosirii:

- deprinderi motrice de bază şi utilitaraplicative - sunt utilizate, preponderent, în viaţa de zi cu zi în dezvoltarea umană, dar şi pentru practicarea unor ramuri de sport sau probe sportive/ aplicative (mersul, alergarea, săritura, aruncarea, prinderea, târârea, căţărarea, escaladarea, tracţiunea-împingerea, transportul de greutăţi/ obiecte etc.);

- deprinderi motrice specifice ramurilor şi probelor sportive (elementele şi procedeele tehnice specifice).

c) În funcție de nivelul participării sistemului nervos la formarea şi valorificarea lor:

- deprinderi motrice propriu-zise, care se execută de foarte multe ori (stereotipuri dinamice, cum ar fi elementele și procedeele tehnice specifice gimnasticii, patinajului, săriturilor la platformă etc.);

- deprinderi perceptiv-motrice, în care mediul ambiant influențează formarea şi valorificarea lor (deprinderi specifice schiului, oinei, baseballului, tirului cu talere etc.);

- deprinderi inteligent-motrice, în care partenerii şi adversarii de întrecere influenţează formarea şi, mai ales, valorificarea acestora (deprinderi specifice jocurilor sportive, sporturilor combat, scrimei etc. $)^{4}$.

În procesul de instruire militară, categoriile de deprinderi motrice menționate se învață în 
cadrul activității de educație fizică și sport, însă complexitatea acțiunilor militare presupune formarea unui bagaj vast de deprinderi, cum ar fi: deprinderi motrice de bază și utilitar-aplicative, adaptate câmpului de luptă (marș, alergare în teren variat, aruncarea grenadelor, mers târâș cu armamentul și echipamentul din dotare, cățărare pe diverse obstacole din teren, escaladare versanți abrupți, transport de echipamente și materiale specifice sau de răniți, săritură în lungime, adâncime, înălțime etc.); deprinderi motrice specifice armelor și specialităților militare; deprinderi perceptivmotrice (tragerea cu armamentul din dotare fiind o deprindere care trebuie însușită de toți militarii); deprinderi inteligent-motrice (le întâlnim, cu preponderență, în procesul de instruire pentru lupta apropiată, cu sau fără armamentul și echipamentul din dotare) etc.

Așadar, putem afirma că deprinderile motrice reprezintă caracteristicile de ordin calitativ ale actelor și acțiunilor motrice învăţate. Formarea deprinderilor motrice (în unele cazuri, reformarea sau reconstrucția) reprezintă obiectivul fundamental al educației fizice, antrenamentului sportiv, kinetoterapiei sau al altor domenii socioprofesionale, printre care se numără, în mod evident, aşa după cum am observat, și instruirea militară.

Principalele mecanisme și procese fiziologice implicate în formarea și consolidarea deprinderilor motrice sunt fenomenele de dezvoltare și de întărire a legăturilor temporare, de iradiere, concentrare și inducție a proceselor nervoase fundamentale (excitația și inhibiția). În urma organizării și sistematizării continue a proceselor nervoase, se formează un stereotip dinamic. Indicațiile instructorului în timpul efectuării exercițiilor, aprecierile acestuia completează şi clarifică senzațiile, percepțiile și reprezentările militarului, cunoştințele şi imaginea despre acțiune, îl mobilizează și îi dirijează efortul spre realizarea unor execuţii cât mai corecte.

Formarea și consolidarea deprinderilor motrice se realizează treptat, prin numeroase repetări. Procesul de formare și perfecţionare a stereotipului dinamic care stă la baza deprinderilor motrice parcurge mai multe etape. Timpul necesar elaborării acestui stereotip și a fiecărei etape în parte diferă de la individ la individ sau de la o acțiune motrică la alta, fiind dependent de: complexitatea mișcărilor care intră în componența deprinderii de însușit; experiența motrică anterioară a executantului; nivelul de dezvoltare a calităților motrice solicitate; nivelul de dezvoltare a capacităţii de coordonare; interesul, motivaţia participanţilor la acțiunea respectivă, care determină concentrarea atenției, participarea conștient-activă, mobilizarea, toate susținute prin efortul de voință.

Referitor la etapele de formare a deprinderilor motrice, literatura de specialitate prezintă diferit numărul și denumirea acestora, în funcție de domeniul care le tratează, chiar dacă, analizândule atent, toate conduc spre aceleași concluzii. În acest sens, am ales să prezint succint, fără a le mai descrie, etapele psihologice și fiziologice de formare a deprinderilor motrice și, mai amănunțit, și în detaliu, etapele din punct de vedere metodic.

Așadar,psihologia prezintă patru etape (faze)ale formării deprinderilor motrice, astfel: etapa iniţială, în care executantul se orientează și familiarizează cu acţiunea; etapa însuşirii fiecărui element în parte al acțiunii; etapa unificării elementelor acțiunii însuşite separat; etapa automatizării. Din punct de vedere fiziologic, în formarea și consolidarea deprinderilor motrice, distingem următoarele etape: cea a mișcărilor inutile care se execută într-o manieră grosolană, fără coordonare; etapa mișcărilor realizate în acord cu scopul acțiunii, dar prin contracții musculare excesive; etapa însușirii propriu-zise, a fixării și stabilizării deprinderii motrice 5 .

Potrivit metodicii educaţiei fizice şi sportului, învățărea motrică se realizează prin următoarele etape cu principalele lor obiective, astfel:

- etapa iniţierii sau , însuşirii primare”, în care se pun bazele tehnice de execuţie a mișcării respective. Principale obiective specifice acestei etape sunt: formarea, prin explicare şi demonstrare, a unei reprezentări asupra deprinderii ce trebuie învăţată; formarea unui ritm cursiv de execuţie; dezasamblarea deprinderii respective, în cazul în care este posibil şi dacă este necesar, în elemente componente ce se exersează analitic separat; prevenirea greşelilor tipice de execuţie sau corectarea acestora. Predominant pentru această etapă inițială este volumul efortului fizic;

- etapa consolidării deprinderii motrice, care are ca obiective principale următoarele: desăvârșirea tehnicii de execuţie a mișcării, în acord cu caracteristicile optime spațio-temporale; crearea 
premiselor pentru executarea deprinderii în condiţii variate, prin întărirea legăturilor temporale, ca urmare a faptului că aceasta este exersată în condiţii relativ şi predominant constante, standardizate; corectarea/îndreptarea, cu prioritate, a eventualelor greşeli individuale de execuţie. Este faza creşterii rolului intensităţii efortului fizic, al controlului sau autocontrolului nivelului de execuţie;

- etapa perfecţionării deprinderii motrice. Obiectivele principale în această etapă sunt: creșterea numărului de variante de execuţie a deprinderii respective, prin realizarea procedeelor tehnice specifice la un nivel superior; exersarea acesteia în condiţii cât mai variate şi similare celor întâlnite în practică, cu preponderență, în activitatea competiţional-sportivă; cuprinderea deprinderii respective în înşiruiri de alte deprinderi motrice şi executarea combinaţiilor rezultate cu uşurinţă, cursivitate, precizie şi eficienţă. Specificitatea acestei etape este dată de complexitatea efortului fizic, care intervine cu un aport substanţial la realizarea finalităților propuse ${ }^{6}$.

În cadrul procesului de formare a deprinderilor motrice, mai ales a celor cu specific militar, se identifică fenomene de transfer, deprinderileînsuşite anterior influențând favorabil sau nefavorabil elaborarea altora noi. Influența favorabilă sau pozitivă se numește transfer, iar cea nefavorabilă sau de frânare, interferență (transfer negativ).

Transferul se produce atunci când există elemente comune sau asemănătoare între deprinderile formate anterior și cele în curs de însușire. Transferul nu se poate rezuma numai la simpla asociere mecanică între elementele identice ale deprinderilor vechi și noi, ci trebuie să fie rezultatul unui proces de analiză și sinteză, de generalizare conștientă a experienței motrice. Pentru a favoriza acest proces, militarii trebuie ajutați prin explicații cât mai precise, în măsură să evidențieze asemănările și deosebirile, să contureze exact structura, natura și caracteristicile elementelor care compun acțiunea nouă.

În ceea ce privește transferul negativ, împrumutul se suprapune, înlocuind un element nou neînsușit, cu un element cunoscut, cu o altă structură motrică. În acest caz, procesul de elaborare a deprinderii noi este îngreunat, frânat. Transferul negativ sau interferența se poate produce și de la o deprindere nouă, în curs de consolidare, la alta veche, care nu a fost fixată suficient.
În condițiile în care avem de a face cu absența exercitiilor fizice sau cu repetarea acestora la intervale mari, cu certitudine, se produce o slăbire a deprinderii motrice, o pierdere a preciziei și ușurinței în executarea mișcărilor componente. Acest fenomen se datorează inhibiției, care acționează în sensul stingerii legăturilor temporare, deprinderile motrice fiind reflexe condiționate, cu un grad mai redus de stabilitate.

$\mathrm{Cu}$ privire la deprinderile formate pe fondul reflexelor de apărare, care abundă în mediul militar (schi, înot, sporturile combat etc.), cazurile de uitare sau de pierdere completă sunt foarte rare, chiar imposibile. Acest aspect se explică prin prisma faptului că cel de-al doilea sistem de semnalizare (baza pentru formarea gândirii verbale și logice despre lumea înconjurătoare, imaginația din memoria umană) are posibilitatea de a reactualiza legăturile temporare, în lipsa execuției, a exercițiilor practice. $\mathrm{Cu}$ toate că se pierde caracterul de automatizare, sub controlul și îndrumarea conștiinței, mișcările pot fi efectuate cu relativă ușurință și precizie.

Așa cum menționam, în mediul militar, deprinderile motrice de bază, precum mersul, alergarea, săriturile, aruncarea, transportul de greutăți, căţărarea etc., sunt transformate în deprinderi utilitar-aplicative specifice, astfel: de trecere a diferitelor parcursuri cu obstacole; de ridicare şi transport de greutăţi (materiale și echipamente); de luptă apropiată cu armamentul din dotare; de trecere a cursurilor de apă cu echipamentul militar şi cu armamentul din dotare; de traversare/trecere a versanţilor muntoşi, iarna sau vara, cu şi fără schiuri şi alte echipamente specifice etc.

În acest mod, instruirea pentru luptă brodează acţiunile pe rezultatele obținute în urma procesului instructiv al activității de educaţie fizică militară și sport, iar această activitate, la rândul ei, studiază structurile tuturor acţiunilor de instruire, natura şi durata eforturilor care urmează a fi depuse, mediul şi locul de desfăşurare a misiunilor în care sunt implicaţi militarii.

În concluzie, deprinderile motrice, aptitudinile şi cunoştinţele se dobândesc în urma unui amplu proces de instruire, orientat şi condus ştiinţific pentru atingerea obiectivelor propuse. Dezvoltarea unui bagaj vast de deprinderi motrice şi abilităţi de ordin psihic, în concordanţă cu cerinţele 
conflictelor militare moderne, se impune tot mai pregnant. Stresul psihic, cauzat de multitudinea de factori solicitanţi, specifici mediului operaţional, precum şi scăderea capacităţii de efort fizic nu pot fi înlăturate, dar efectele lor pot fi, cu certitudine, reduse prin formarea unor deprinderi necesare îndeplinirii întregului spectru de misiuni în care militarii sunt angrenaţi. $\mathrm{Cu}$ alte cuvinte, succesul forţelor angajate în conflictele militare depinde în mare măsură de valoarea prestaţiei motrice şi de nivelul calităţilor psihice ale personalului care deserveşte armamentul, echipamentele și tehnica de luptă. Nivelul aptitudinal-motric reprezintă elementul esențial al valorii operaţionale a structurilor militare din compunerea armatei.

\section{NOTE:}

1 A. Dragnea și colab., Educație fizică și sport - teorie și didactică, Editura FEST, București, 2006, p. 130.

2 Gh. Cârstea, Teoria și metodica educației fizice și sportului, Editura AN-DA, București, 2000, p. 17.

$3 \mathrm{https} / /$ pregatirefizica.wordpress.com/2017/06/13/dep rinderile-motrice, accesat la 08.05.2021.

4 Gh. Cârstea, op.cit., pp. 71-72.
$5 \mathrm{http} / / /$ educatie-fizica.ro/invatarea-motrica-formareadeprinderilor-motrice, accesat la 08.05.2021.

6 Gh. Cârstea, op.cit., pp. 70-71.

\section{BIBLIOGRAFIE}

Bota A., Kinesiologie, Editura Didactică şi Pedagogică, R.A., Bucureşti, 2007.

Cârstea Gh., Teoria și metodica educației fizice și sportului, Editura AN-DA, București, 2000.

Dragnea A. şi colab., Educaţie fizică şi sport teorie şi didactică, Editura FEST, Bucureşti, 2006.

Epuran M., Motricitate şi psihism în activităţile corporale, Editura FEST, Bucureşti, 2011.

Pelmuș A.D., Dezvoltarea capacității motrice a personalului militar, Editura Centrul TehnicEditorial al Armatei, București, 2021.

https://pregatirefizica.wordpress.com/2017/06/13/ deprinderile-motrice

http://educatie-fizica.ro/invatarea-motricaformarea-deprinderilor-motrice

https://www.academia.edu/17334296/Invatarea _deprinderilor_motrice 